\title{
ASSESSMENT OF EFFECTIVENESS OF COASTAL PROTECTION STRUCTURES FOR ENSURING A CONSTANT LAGOON-SEA WATER EXCHANGE IN THE NORTH-WESTERN BLACK SEA REGION
}

\author{
Dmytro KUSHNIR ${ }^{1}$, Yuri TUCHKOVENKO
}

DOI: $10.21163 / G T \_2018.131 .07$

\begin{abstract}
:
Coastal lagoons of the Northern-Western Black Sea region show a long-term tendency in decreasing their water volume while increasing in water salinity as well as in nutrient and pollutant concentration. This occurs due to a limited connection between the lagoons and the sea, on the one hand, and the significant negative freshwater balance, on the other hand. To compensate this, a constant multi-directional water exchange with the sea through connecting canals is needed for the lagoons. However, the connecting canals require marine engineering, ensuring the protection from the sand deposition at their sea parts, in order to guarantee a year-round bidirectional 'sea-lagoon' water exchange. In the present work, a case study has been implemented to the Tylihulskyi Lyman lagoon, for which the existing canal has been reconstructed. A coupled numerical model for currents, waves and sediment transport has been used to estimate the efficiency of various engineering options of hydroengineering protective structure, which is being constructed at the sea part of the restored artificial canal, connecting the Tylihulskyi Lyman Lagoon with the Black Sea. A real storm pattern with maximum sediment transport has been simulated. Four variants of the engineering design of hydroengineering structure for wave and sediment protection were considered. Results have shown that the optimal solution for the hydroengineering structure is the variant comprised of parabolic-shaped groynes and the underwater breakwater. Reduction in the intake of sediments into the canal is achieved by sedimentation at the entrance to the protective structure. Therefore, under a long-term operation of the 'sea-lagoon' connecting canal, measures for removing the depositions accumulated in the inner sections of the protective structure should be implemented. The results of this study can be generalized to other lagoons of the Azov-Black Sea basin.
\end{abstract}

Key-words: North-Western Black Sea Region, lagoons, canals, sediment deposition, modelling.

\section{INTRODUCTION}

Coastal lagoons have an important socio-economic significance, providing a substantial natural-resource potential (fisheries and aquaculture, tourism and recreation, agricultural developments etc.), that serves the respective needs of the society (Gönenç \& Wolflin, 2005). One of the intrinsic features of coastal lagoons is their connection with the sea via one or more inlets in the barrier (bar) between the lagoon and the sea. The marine part of these inlets can be clogged down with sediment, which is getting transported by the waves, tides, storm surges, and nearshore currents.

There are 16 coastal lagoons situated in the Ukrainian North-Western Black Sea region. Most of the lagoons, or 'the lymans', as they are called locally, have a man-induced and intermitted connection with the Black Sea due to climate changes and anthropogenic transformation of the sandy barriers (bars), which separate lagoons from the sea.

\footnotetext{
${ }^{1}$ Odessa State Environmental University, 15 Lvivska str., Odessa,Ukraine, 65016,dkush@ukr.net.
} 
Small artificial inlets (canals) have traditionally been laid in the sandy bars, functioning only for a few months a year: to let young fish pass into the lagoon from the sea in spring for fattening and to catch fish that leave the lagoon in autumn. The regular cessation of the water transmission through the canals is implicated from the sand accretion on their marine part. Under continuing absence of the conjunction with the sea, the lagoons demonstrate a long-term tendency of water volume decrease and consequent shallowing, as well as increased water salinity and concentration of nutrients and pollutants in their water (Brito et al., 2016).

Significant deficiency in the annual freshwater balance has been formed in the lagoons in recent decades as a result of climate changes: increase of air temperature and growth of evaporation rates, reduction of atmospheric precipitation and freshwater inflow from tributaries (Loboda \& Bozhok, 2015). Current operational mode of the 'sea-lagoon' interconnecting canals and their low water-transmitting capability make it possible to compensate the deficiency in the water balance of the lagoons, although do not ensure their complete flushing (Viero \& Defina, 2016). Bielecka et al. (2015) showed that the effective solution to the problem of stabilization of hydro-ecological regime of the lagoons lies in ensuring the constant intra-annual multi-directional water exchange with the sea through the canals with a higher water-carrying capacity.

During the winter-spring period of high water, initiated by rivers and streams flowing into the lagoons, the excess of the monthly average water level in the lagoons over the sea level takes place under minimal evaporation rate from the lagoons' water surface. Along with the wind-induced water level variations in the sea and in the lagoons, this excess is expected to provide the multi-directionality of the 'sea-lagoon' water exchange (Tuchkovenko, Kushnir \& Loboda, 2015).

The multidirectional water exchange with the sea will lower the rates of salt accumulation in the lagoons and decrease the trophicity of their water, since the sea water typically has much lower salinity and nutrient concentration than the water within the lagoons (Tuchkovenko, Bogatova \& Tuchkovenko, 2015). For guaranteeing a year-round operational mode of the canals, it is necessary to protect them from shoaling, resulted from the deposition of sand, which is being transported at the sea side (Tuchkovenko \& Loboda, 2014).

The objective of this work is to estimate, on the basis of the results of numerical modelling, the efficiency of different variants of the engineering design of hydroengineering structure, located in the sea part of the reconstructed artificial canal, connecting the Tylihulskyi Lyman Lagoon (TLL) with the sea, in terms of minimizing the deposition of sediment.

\section{MATERIAL AND METHODS}

\subsection{Study site}

The Tylihulskyi Lyman Lagoon (46.65833-47.08833 $\left.{ }^{\circ} \mathrm{N}, 30.955-31.21167^{\circ} \mathrm{E}\right)$ is situated on the Ukrainian part of the North-Western Black Sea coast (Fig. 1). It has a surface area of 129 million $\mathrm{m}^{2}$ and a water volume of 693 million $\mathrm{m}^{3}$. The length of the lagoon is now $52 \mathrm{~km}$ and the width varies from 0.2 to $5.4 \mathrm{~km}$ in particular sections. The mean depth in the lagoon is $5.4 \mathrm{~m}$ and the maximum depth is $22.2 \mathrm{~m}$ in the southern part. The northern part of the lagoon is shallow, with depths less than $4 \mathrm{~m}$ (Tuchkovenko, Loboda \& Khokhlov, 2015). 
The lagoon is separated from the Black Sea with a natural sand bar. In the late 1950s, in an effort to connect the lagoon with the sea, an artificial canal for fishery purposes was laid across in the bar. The canal is $3.3 \mathrm{~km}$ long and $3 \mathrm{~m}$ deep. The southern part of the canal, which is adjacent to the sea, has become much shallower over the years (Fig. 1). The bottom depth there averages a few dozen of centimeters only.

Since 2001, the canal has been in unsteady operation, functioning merely for several months in a year. For instance, in 2013 the canal was opened for 40 days in spring and approximately for 30 days in autumn. In spring and autumn 2014 the canal functioned for 26 and 35 days respectively. As a result of the weak water exchange with the sea, insufficient to compensate for the deficit of fresh water balance, the water level in the lagoon has decreased by $1.5 \mathrm{~m}$ in 5 years, compared to the sea level. Water salinity in the lagoon has increased from 19-20 ppt to 27-35 ppt over this period.

The Tylihulskyi Lyman Lagoon along with the territories adjacent to its coast is included to the Natural Reserve Fund of Ukraine and to the network of sites of Important Bird and Biodiversity Area (IBAs) Programme. It is designated as a Wetland of International Importance according to the Convention on Wetlands, called the Ramsar Convention (Gubanova et al., 2015).

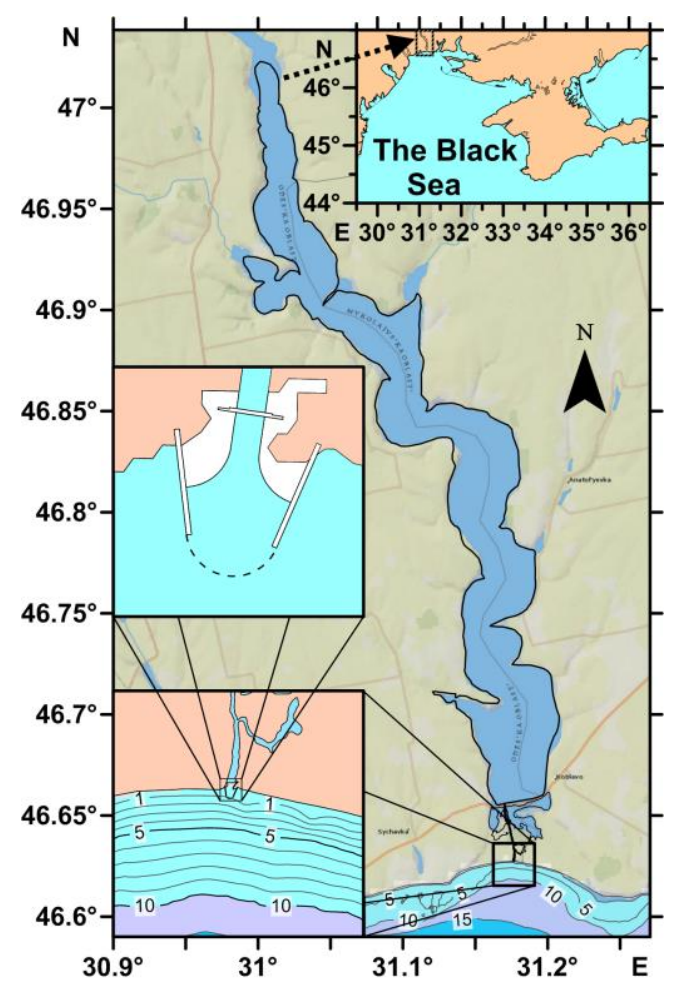

Fig. 1 Map showing the Tylihulskyi Lyman Lagoon (TLL) with adjacent coastal area. Insets: locations of the TLL on the North-Western Black Sea coast, the 'sea-lagoon' interconnecting channel and the constructed hydroengineering structure for wave and sediment protection. 
For stabilizing the hydro-ecological regime of the lagoon, a project of the reconstruction of the 'sea-lagoon' connecting canal has been developed. The project involves the canal deepening to $2 \mathrm{~m}$ relative to the mean annual sea level mark and construction of a hydroengineering structure for wave and sediment protection on the sea end of the canal. The problem of choosing the most effective embodiment of this hydroengineering structure is considered in this article.

\subsection{The Delft3D modelling suite}

For this case study, a 2D version of the Delft3D-FLOW numerical hydrodynamic model, coupled online with the Delft3D-WAVE module for calculating the propagation and transformation of wind wave parameters (based on the third generation SWAN spectral model, version 40.72ABCDE) was applied (http://oss.deltares.nl/web/delft3d).

This integrated modelling suite can simulate the stirring, movement and deposition of the set of different sediment fractions under the influence of wind-wave currents. The Delft3D-FLOW hydrodynamic module solves two- and three-dimensional Navier-Stokes and transport equations for an incompressible fluid under the shallow water and Boussinesq assumption on the curvilinear or rectilinear grid. The Delft3D-WAVE module simulates the propagation, breaking and transformation of the wind waves at a distance from the shore and in the shallow water, assimilating input information about the water level and currents, modelled by the Delft3D-FLOW module. Simultaneously, the sediment transport and morphology module Delft3D-MOR calculates bed load and suspended sediment transport and bottom deformations at each flow time step.

The overall mathematic structure of the Delft3D morphodynamic model is described by Lesser et al. (2004). The model was used for direct application at the Frisian Inlet, located in the Dutch Wadden Sea, to investigate the long-term development of the bathymetry of tidal inlet systems (Van Leeuwen, Van der Vegt \& de Swart, 2003).

Using 2DH and 3D hydro-morphodynamic models, which were applied to the Patos Lagoon, a coastal lagoon connected to the inner Shelf of Cassino Beach, South Brazil, Vinzon et al. (2009) concluded that the remote wind has the most influence on the lagoon's water exchange with the sea.

The first simulation scenario with multiple sediment fraction settings applied to hindcast the morphologic change in San Pablo Bay, a subembayment of the San Francisco Estuary, California, USA, on a decadal time scale by means of a 3-D numerical model (Delft3D), was presented in the work (Van der Wegen, Jaffe \& Roelvink, 2011).

Transport of a mixture of cohesive sediments and sand in the Paranagua Estuarine Complex in the south of Brazil, which houses a navigation canal from the Atlantic Ocean to a busy harbor, was simulated by means of a 3-D numerical model (Delft3D) for sediment transport coupled with wave-current models (Mayerle et al., 2015).

\subsection{Model set-up}

In the present study, both the bedload and suspended load transport of sediments were computed according to Bijker formulation, which is often used for coastal areas and takes into account the combined effect of the nearshore currents and wave stirring on the transport of sediment fractions (Smit, Reniers \& Stive, 2012). 
A domain-decomposition technique (Deltares, 2016) was used for the detailed spatial discretization in the marine area of the 'sea-lagoon' interconnecting canal. The Tylihulskyi Lyman lagoon and the adjoining sea water area of $50 \mathrm{~km} 2$ were schematized using a curvilinear grid with varying cell size from about $75 \mathrm{~m}$ at the coast to $300 \mathrm{~m}$ near the open

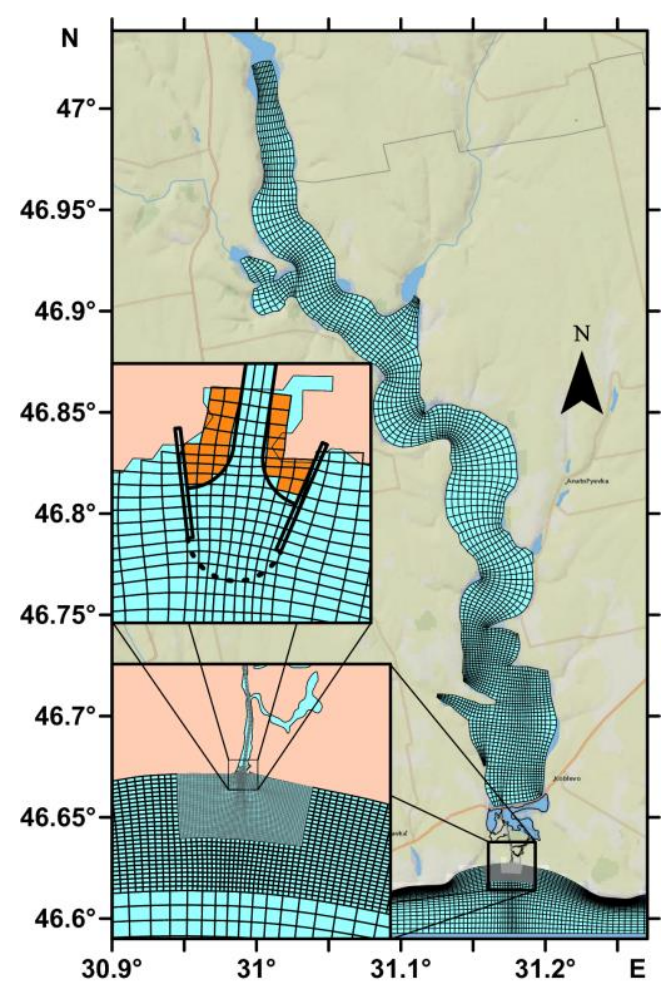

Fig. 2. Modelling grid with insets showing domain decomposition domains at the sea area near the 'sea-lagoon' interconnecting canal.

sea boundaries. Inside the main grid, two refined sub-grids were created with sequentially increasing cell sizes of 35-55 $\mathrm{m}$ and 7-16 m, respectively (Fig. 2).

Initial bathymetry of the sea area adopted in the model was based on navigational charts issued by Ukrmorcartographia branch of State Hydrographic Service of Ukraine (http://charts.gov.ua/index_en.htm). Bathymetry of the lagoon was composed of the measurements data, taken between 2010 and 2012.

Four fractions of non-cohesive sediment with different particle sizes were considered in the simulations, in accordance with the engineering and geological survey data. These fractions, conventionally named as 'pulverescent sand', 'fine sand-1', 'fine sand-2' and 'medium sand', were characterized by different median particle diameter $D_{50}$ of 0.167 $\times 10^{-3} \mathrm{~m}, 0.192 \times 10^{-3} \mathrm{~m}, 0.214 \times 10^{-3} \mathrm{~m}$ and $0.217 \times 10^{-3} \mathrm{~m}$, respectively.

In the bed, three layers of sediments with different spatially varying thickness and composition were specified.

A real storm situation of 3.5 days duration, caused by a southern wind with a speed up to $12 \mathrm{~m} \mathrm{~s}-1$, was simulated. The storm was observed from 12.00 on May 152010 to 00.00 on May 192010 at the nearest to the lagoon hydro-meteorological station 'Port 'Yuzhny'. 
Observational data from this station about water level, wind speed and direction, and wind waves parameters (Fig. 3), were used to set the boundary conditions at vertical (water-air) and lateral (sea) open boundaries of the computational domain.

The following variants of the engineering design of hydroengineering structure located in the marine part of the 'sea-lagoon' canal were simulated:
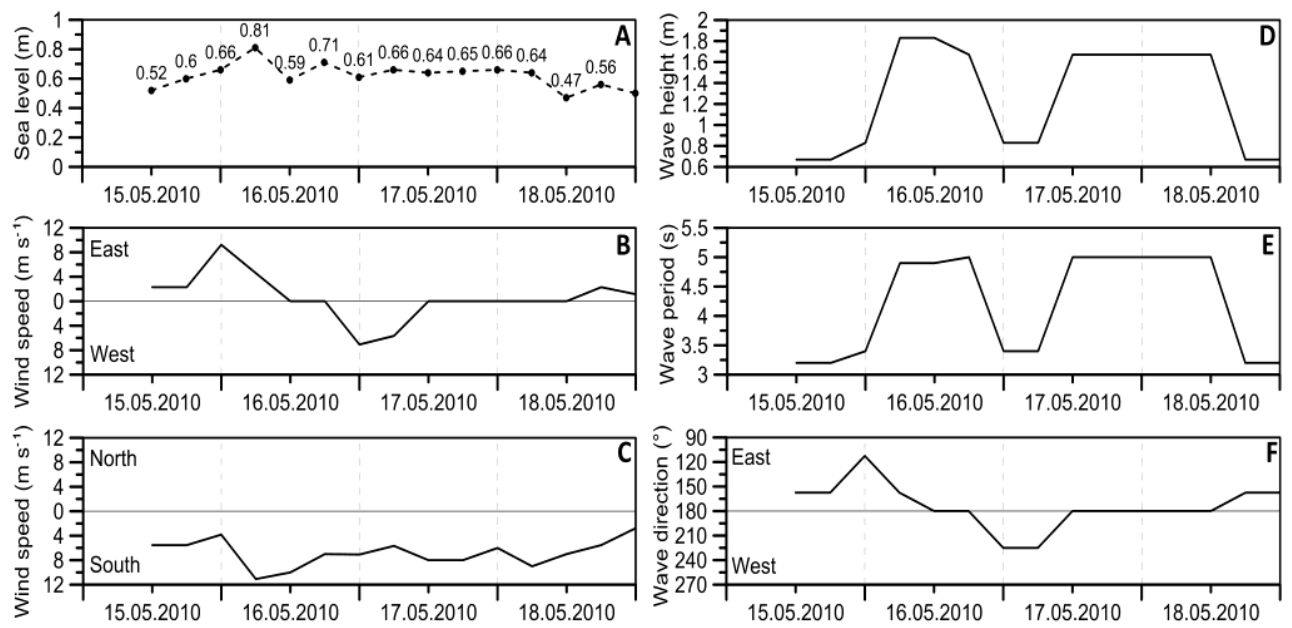

Fig. 3 Input hydro-meteorological data, used in simulations: sea level (A), wind speed at 10 meter in the East-West direction (B) and North-South direction (C), significant wave height (D), wave speed

(E) and wave direction $(\mathrm{F})$ recorded at the hydro-meteorological station 'Port 'Yuzhny'.

- Variant 0: the canal without the hydroengineering structure for wave and sediment protection;

- Variant 1: the canal with the hydroengineering structure in the shape of two groynes $90 \mathrm{~m}$ long, placed at \pm 75 angle to the shore and connected by an arched underwater breakwater $98 \mathrm{~m}$ long. A distance between the groynes at the structure entrance is $65 \mathrm{~m}$, the bottom mark inside the structure is minus $2.6 \mathrm{~m}$ in the Baltic Height System 1977 (BHS-77);

- Variant 2: the canal with the hydroengineering structure in the shape of two groynes $125 \mathrm{~m}$ long with curved extreme ends without the underwater breakwater. The distance between the groynes at the structure entrance is $25 \mathrm{~m}$, the bottom mark inside the structure is minus $2.6 \mathrm{~m}$ in BHS-77;

- Variant 3: the hydroengineering structure on the canal sea part is constructed in the shape of a spur dyke: two parallel cross-shore groynes $250 \mathrm{~m}$ long, with a distance of $32 \mathrm{~m}$ between them. The bottom mark inside the structure is minus $2.11 \mathrm{~m}$ in BHS-77.

A reconstructed interconnecting canal with a bottom mark of minus $2.11 \mathrm{~m}$ in BHS-77 and a width of $23 \mathrm{~m}$ was considered for all above-mentioned variants.

A computational time step was set to 9 seconds to all domain decomposition domains. Propagation and transformation of wind wave parameters were modelled online with hydromorphodynamic simulations, with a 30-minute interval. The initial conditions for water level in all modelling domains matched together with boundary conditions at the start time of the simulation and were set to a uniform value of plus 0.12 meters in BHS-77. 


\section{RESULTS AND DISCUSSION}

The efficiency of different variants of hydroengineering structure for wave and sediment protection in the sea part of the 'sea-lagoon' interconnecting canal was evaluated on the basis of sediment transport intensity near the canal entrance.

Fig. 4 shows modelled significant wave heights in meters and mean wave directions. The depth averaged currents for different options of the 'sea-lagoon' canal reconstruction are shown in Fig. 5. The passing of waves to the sea part of the connecting canal is being blocked most successfully under variant 1 of the structure, which includes the construction of the underwater breakwater (Fig. 4B). Without the underwater breakwater (variants 2 and 3 ), waves are passing inside the protective structure that leads to the formation of a jet directed from the entrance of the sea part of the structure towards the sea end of the canal (see Figs. 5C, 5D).
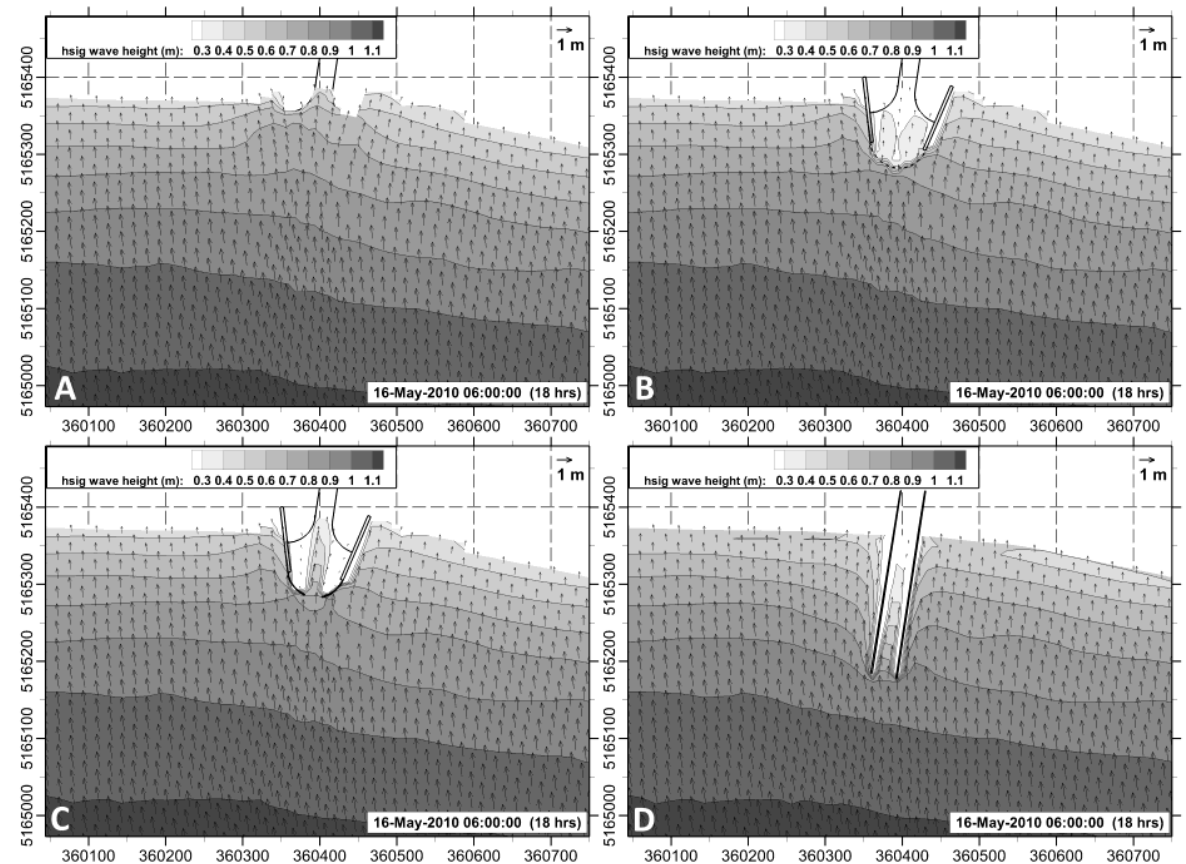

Fig. 4. Computed significant wave heights and mean wave directions after 18 hours from the start of the simulation under different variants of the 'sea-lagoon' canal reconstruction: variant 0 (A), variant

1 (B), variant 2 (C), variant 3 (D).

Fields of total sediment unit flux are shown in Fig. 6. When implementing variant 1 of the hydroengineering structure, the intensity of sediment transport in the interior of the structure and at the entrance to the 'sea-lagoon' canal reaches to its minimum. The maximum sediment transport directed towards the channel corresponds to simulated variant 0 without the protective hydroengineering structure. The area of intensive sediment transport with explicit directionality from the entrance of the structure towards the sea end of the canal is being formed in the simulations with variants 2 and 3 (Figs. 6C, 6D). 

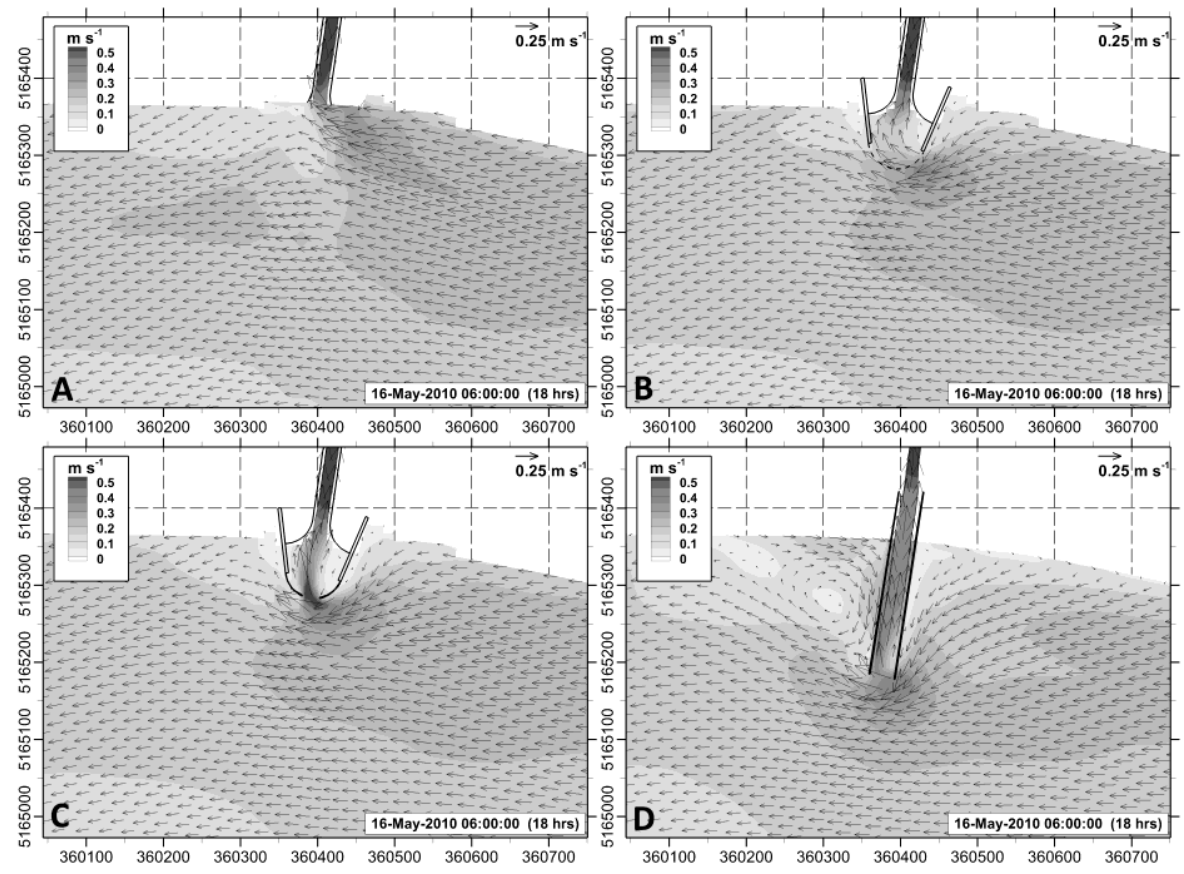

Fig. 5. Depth averaged currents after 18 hours from the start of the simulation under different variants of the 'sea-lagoon' canal reconstruction: variant 0 (A), variant 1 (B), variant 2 (C), variant 3 (D).

The results above support the conclusion that the most effective variant of the hydroengineering protective structure in terms of minimizing the sediment transport into the canal is the variant 1 . The variant 3 of the protective structure is the second in effectiveness amongst the modelled variants.

In Fig. 7 are shown the final depth changes at the end of the modelling period in meters, obtained from simulations under different variants of the 'sea-lagoon' canal reconstruction. Reduction in the intake of sediments into the canal is achieved by sedimentation at the entrance to the protective structure caused by the decrease in transporting capability of the hydrodynamic flow. Essentially, protective structures are the traps for suspended sediment coming from the open sea part of the modelling domain. Therefore, under a long-term operation of the protective structures, measures for removing the depositions accumulated in their inner sections should be implemented. It is seen that bands of erosion are formed inside the protective structure in the variants 2 and 3 (Figs. 7C, 7D), which increases the transport of sediments into the connecting channel.

The considered variants of hydroengineering structures for wave and sediment protection were analyzed additionally for compliance with the fishery requirements imposed on the activity in the lagoon and in the canal. Under the variant 3 of the protective structure (the spur dyke), dykes $250 \mathrm{~m}$ long completely block the shoreline area, preventing the migration of fish from the sea to the canal. The spurs also block a longshore sediment transport, which will lead to the development of such phenomenon as downstream scour and other adverse morpho-lithodynamic processes. 


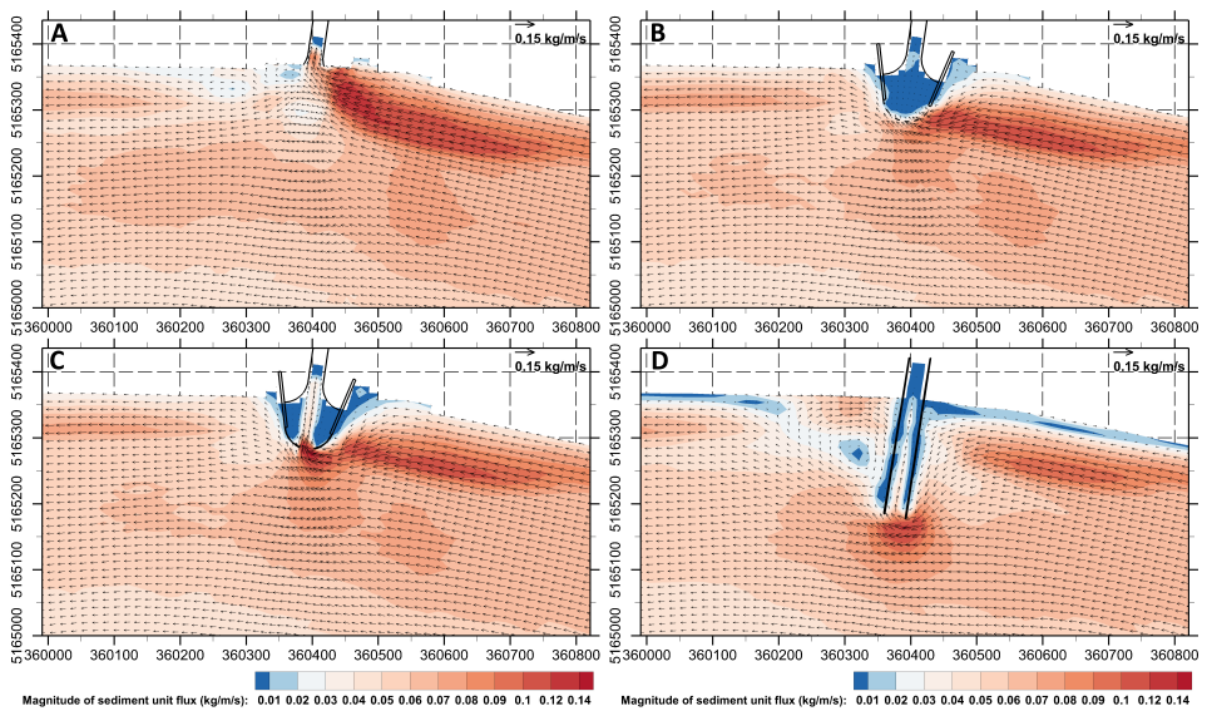

Fig. 6. Computed patterns of total sediment unit flux after 18 hours from the start of the simulation under different variants of the 'sea-lagoon' canal reconstruction: variant 0 (A), variant 1 (B), variant $2(C)$, variant $3(D)$.
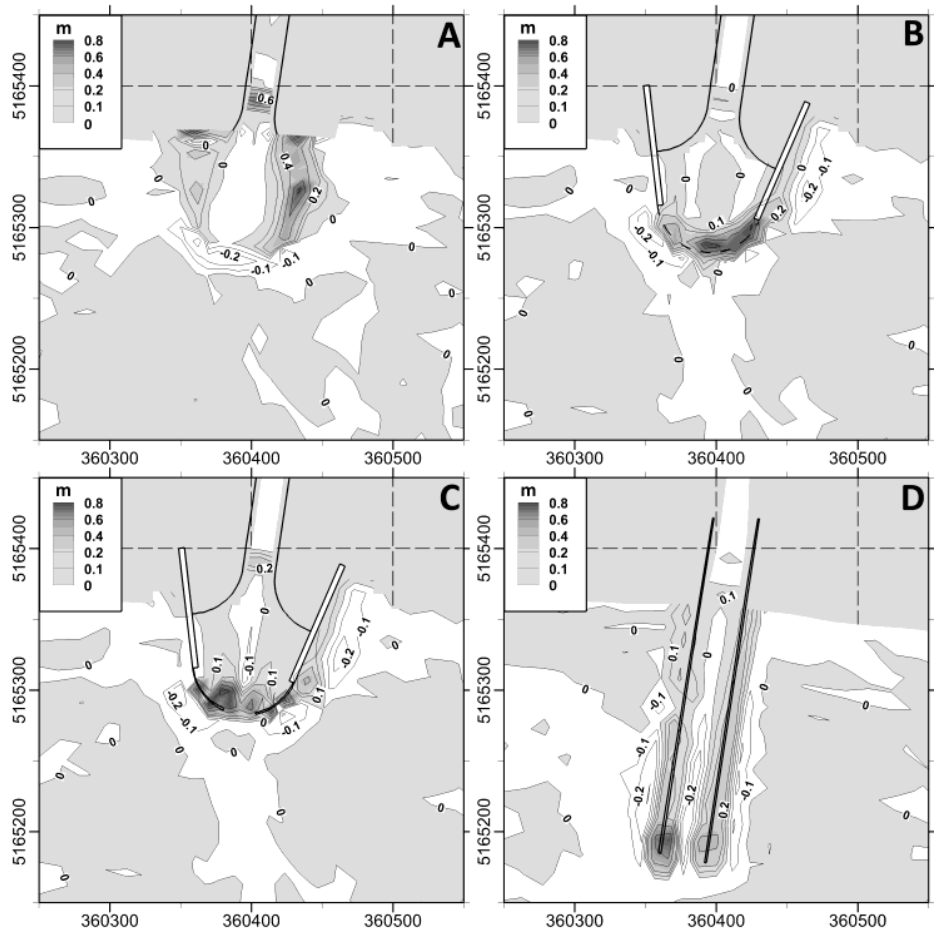

Fig. 7. Calculated depth change at the 'sea-lagoon' canal entrance under different variants of its reconstruction: variant 0 (A), variant 1 (B), variant $2(C)$, variant 3 (D). 
At the same time, variant 1 (a parabolic arrangement of dykes with the underwater breakwater) is perfectly adequate for fishery purposes in its parameters and intended mode of operation.

\section{CONCLUSIONS}

The most effective variant of the hydroengineering structure for wave and sediment protection in the sea part of the 'Black Sea-Tylihulskyi Lyman Lagoon' interconnecting canal was chosen, based on the results of the modelling of wave and wind induced currents and sediment transport using the suite of process-based numerical models.

This variant, which ensures a minimal deposition of sediment, represents two groynes $90 \mathrm{~m}$ long, placed at \pm 75 angle to the shore and connected by the arc-shaped underwater breakwater $98 \mathrm{~m}$ long at their sea ends. A long term operation of the structure presumes a recurring removal of the sediment accumulated in its interior.

Due to the significant increase in the deficit of the annual fresh water balance in the lagoons of the North-Western Black Sea caused by climate changes, the problem of ensuring the regular operation of artificial canals connecting the lagoons with the sea is still to be solved for a number of lagoons of the Azov-Black Sea basin: Molochny Lagoon, Budak Lagoon, Dofinovsky Lagoon, Tuzlov group of lagoons, etc. Therefore, the findings of this study can be generalized to other lagoons of the Azov-Black Sea basin.

\section{R E F E R E N C E S}

Bielecka, M., Robakiewicz, M., Zalevwski, M., Khokhlov, V., Tuchkovenko, Yu. \& Lloret, J. (2015) Lagoons impact integrated scenarios. In: Lillebø, A.I., Stålnacke, P. \& Gooch, G.D. (eds.) Coastal Lagoons in Europe: Integrated Water Resource Strategies. London, IWA Publishing. pp. 211-216.

Brito, A.C, Newton, A., Tett, P. \& Fernandes, T.F. (2012) How will shallow coastal lagoons respond to climate change? A modelling investigation. Estuarine, Coastal and Shelf Science, 112, 98-104.

Deltares (2017). Delft3D-FLOW - Simulation of multi-dimensional hydrodynamic flows and transport phenomena, including sediments - User Manual. Hydro-Morphodynamics. Deltares Systems, Delft, the Netherlands. Available at: http://content.oss.deltares.nl/delft3d/ manuals/Delft3D-FLOW_User_Manual.pdf.

Gönenç, I.E. \& Wolflin, J.P. (eds.) (2005). Coastal Lagoons: Ecosystem Processes and Modeling for Sustainable Use and Development. CRC Press, Boca Raton, Florida, USA.

Gubanova, O.R., Tuchkovenko, Yu.S, Khokhlov, V.M., Stepanenko, S.M., Baggett, S. (2015) The management story of Tyligulskyi Liman Lagoon. In: Lillebø, A.I., Stålnacke, P., Gooch, G.D. (eds.) Coastal Lagoons in Europe: Integrated Water Resource Strategies. London, IWA Publishing. pp. 87-95.

Lesser, G.R., Roelvink, J.A., van Kester, J.A.T.M. \& Stelling, G.S. (2004). Development and validation of a three-dimensional morphological model. Coastal Engineering, 51, 883-915.

Loboda, N. \& Bozhok, Yu. (2015) Impact of climate change on water resources of North-Western Black Sea region. International Journal of Research in Earth and Environmental Sciences, 2, 1-6.

Mayerle, R., Narayanan, R., Etri, T. \& Abd Wahab, A.K. (2015). A case study of sediment transport in the Paranagua Estuary Complex in Brazil. Ocean Engineering, 106, 161-174.

Smit, M.W.J., Reniers, A.J.H.M. \& Stive, M.J.F. (2012). Role of morphological variability in the evolution of nearshore sandbars. Coastal Engineering, 69, 19-28.

Tuchkovenko, Yu.S., Bogatova, Yu.I. \& Tuchkovenko, O.A. (2015) Hydrochemical regime of Tylihulskiy Lyman Lagoon in modern period. Vìsn. Odes. derž. ekol. unìv. - Bull. of OSENU, 19, 126-133 (In Russian). 
Tuchkovenko, Yu.S., Loboda, N.S. \& Khokhlov, V.M. (2015) The physio-geographical background and ecology of Tyligulskyi Liman Lagoon. In: Lillebø, A.I., Stålnacke, P., Gooch, G.D. (eds.) Coastal Lagoons in Europe: Integrated Water Resource Strategies. London, IWA Publishing. pp. 77-85.

Tuchkovenko, Yu.S., Kushnir, D.V. \& Loboda, N.S. (2015) Estimation of the influence of water exchange with the sea conditions on the water level and salinity variability in the Tylihulskyi Lyman Lagoon. Ukr. gìdrometeorol. ž. - Ukr. hydrometeor. J., 16, 232-241. (in Russian).

Tuchkovenko, Yu.S. \& Loboda, N.S. (eds.) (2014) Water resources and hydroecological conditions of the Tylihulskyi Lyman lagoon. TES, Odessa, Ukraine (in Ukrainian).

Van der Wegen, M., Jaffe, B.E. \& Roelvink, J.A. (2011). Process-based, morphodynamic hindcast of decadal deposition patterns in San Pablo Bay, California, 1856-1887. J. Geophys. Res., 116, 122.

Van Leeuwen, S.M., Van der Vegt, M. \& de Swart, H.E. (2003). Morphodynamics of ebb-tidal deltas: a model approach. Estuarine, Coastal and Shelf Science, 57, 899-907.

Viero, D.P., Defina, A. (2016) Water age, exposure time, and local flushing time in semi-enclosed, tidal basins with negligible freshwater inflow. Journal of Marine Systems, 156, 16-29.

Vinzon, S.B., Winterwerp, J.C., Nogueira, R. \& de Boer, G.J. (2009). Mud deposit formation on the open coast of the larger Patos Lagoon-Cassino Beach system. Continental Shelf Research, 29, $572-588$. 